\title{
An identification of students' responses based on solo taxonomy in mathematics learning toward learning activities and learning outcomes
}

\author{
Andi Kaharuddin ${ }^{1}$, Nining Hajeniati ${ }^{1}$ \\ ${ }^{1}$ Lakidende University of Unaaha, Sulawesi Tenggara, Indonesia \\ 凶andikaharuddinunismuhmks@gmail.com*
}

\section{Article Information \\ Submitted April 16, 2020 \\ Revised May 05, 2020 \\ Accepted May 07, 2020}

\section{Keywords}

Activeness;

Learning outcomes;

Response;

Solo Taxonomy.

\begin{abstract}
Solo taxonomy is a classification of real responses from students. This research aims to identify the effect of students' responses based on a solo taxonomy in mathematics learning on learning activity and learning outcomes. This research is a mixed-method with an explanatory sequential design. The data were collected using observation instruments, questionnaires, interviews, and tests. The data was analyzed inferentially and narratively. Based on the results, students who are at the extended abstract response level are classified as very active and having very high learning outcomes, students who are at the relational response level are identified as active and having high learning outcomes, students who are at the multi-structural response level are identified as active and having moderate learning outcomes, students who are at the Uni-structural response level are identified as active and having moderate learning outcomes, and students who are at the pre-structural response level are identified as less active and having low learning outcomes. Thus, it can be interpreted that students' responses based on solo taxonomy in mathematics learning affect activeness and learning outcomes.
\end{abstract}

\section{INTRODUCTION}

The learning process is the main key to the success of learning. The learning process is the process of transferring information from teachers to students. When the learning process takes place, there is an interaction between teachers and students that allows the teachers to be able to recognize the types of characteristics and potential that the students possess. From the learning process, the students will get the opportunity to learn and hone their cognitive abilities. Therefore, the world of education no longer provides direct learning as an effort to develop the students' potential, rather by using learning models, approaches, or thinking frameworks that help students to think critically and be able to grow their creativity.

Kaharuddin (2019) states that the application of the right learning model certainly offers maximum results. Learning outcomes are benchmarks of learning success. However, in the learning process, several problems are often encountered, for example, teachers' understanding of learning models, so that the learning is not implemented properly or optimally. This needs to be considered because it supports the achievement of learning indicators. The role of teachers is needed in utilizing various resources to overcome the problems they face (Ataupah, 2018; Putri, 2014). According to Tomlinson et al (2003), teachers are expected to create a learning condition that can improve the response, activeness, and attractiveness of students so that it will also affect the value of learning outcomes. Teachers are expected to motivate so that students feel more enthusiastic and passionate in each learning session, especially when students are in a state of insecurity. Tawarah (2013) states that the process of exchanging information by 
students through responses toward teacher's questions is related to the questions given by the teacher. In other words, if the level of the teacher's questions is higher, the students' responses are higher too

Knowing students' responses in solving a mathematical problem is very important for teachers. Teachers are expected to be able to explore the students' way of thinking, processing information, and concluding. Thus, teachers can find out the types of mistakes. Mistakes made by students can be a source of information to construct and pose similar questions.

Taxonomy solo is a taxonomy of cognitive processes developed by John Biggs and Kevin Collis. This taxonomy is used to classify the quality of students' responses that can be concluded from the structure of the answers toward the tasks given (Lian \& Yew, 2012) Solo taxonomy can be used to measure the level of achievement of the application of learning as seen from responses toward learning outcomes. (Hasan, 2017; Mulbar et al, 2017) The solo taxonomy can be categorized into five levels of response, namely extended abstract (positive), relational (positive tendency), multi-structural (normal), uni-structural (negative tendency), and prestructural (negative). The five categories or levels indicate the response of students in terms of cognitive understanding needed to answer questions, students' efforts to link their responses toward the questions, consistency, and closure of answers, and the overall structure of answers after the tests. Students' response model based on the solo taxonomy has its framework that can be used to develop the skills or activeness (Lake, 1999; Vrettaros et al, 2006). The students' response model based on a solo taxonomy can describe the process of understanding through skills, activeness, or involvement in the learning process seen from the learning outcomes.

The students' learning outcomes cannot be separated from the learning process. According to Hariyanto (2015), students' learning outcomes can increase due to several factors including student activeness. (Kaharuddin, 2013; Kaharuddin \& Liasambu, 2019; Sadikin \& Kaharuddin, 2019) explain that the indicators of the learning outcomes are response, interest, activeness, and motivation in learning. Therefore, it is very important to see the students' activeness in the learning process because it supports the success of learning processes. Broadly speaking, many variables influence the increase in student learning outcomes.

Students' responses based on solo taxonomy are considered to have an important role in increasing the activeness and learning outcomes. There has been no research that states that there are influences or indications that the solo taxonomy has a major effect on the students' activeness and learning outcomes. However, according to the results of the study by Agustya (2017), responses based on solo taxonomy are in the feasible category. It means that a positive effect on learning outcomes is seen from the learning process. Based on the mentioned research, there are activities done by students in working on the problem, whether it is in the form of group work or independent assignments. It is similar to the findings of research conducted by (Casey \& Azcona, 2017; Novianti et al, 2014; Nurmala et al, 2014; Hendriana et al, 2018; Yang et al, 2019), which discover that in the learning activeness, there is a process of information exchange and changes in students' behavior shown on their activeness. The study by (Purwasih et al., 2018) on students' responses in solving math problems based on the solo taxonomy explains the teaching and learning process gradually paying attention to the level of responses based on the solo taxonomy of the students' skills. According to the Indonesian Dictionary, word skill means the ability in completing a task. It enters the realm of activeness because the activity in question is busy in solving mathematical problems so that it can be assumed that 
process skills are included in the students' activeness.

The brief description above becomes the basic assumption that there is a significant influence on students' responses based on the solo taxonomy on the activeness in the learning process and learning outcomes. Therefore, the formulation of the problem of this research is the identification of students' responses based on the solo taxonomy in mathematics learning towards the activeness and learning outcomes.

\section{METHODS}

This research employed a mixed method. According to Creswell (2012) a mixed-method is a combined research method between qualitative and quantitative methods in a study, both on data collection, analysis, and interpretation so that the research would be more comprehensive, valid, reliable, and objective. The design used was the sequential explanatory design, as explained by Creswell, that the explanatory sequential design is a mixed method of research in gathering quantitative and qualitative information sequentially and is divided into two phases, the first phase is data collection where the quantitative data is then analyzed inferentially. The second phase is the qualitative data collection which then explored narratively. The sequential explanatory design can be seen in Figure 1.

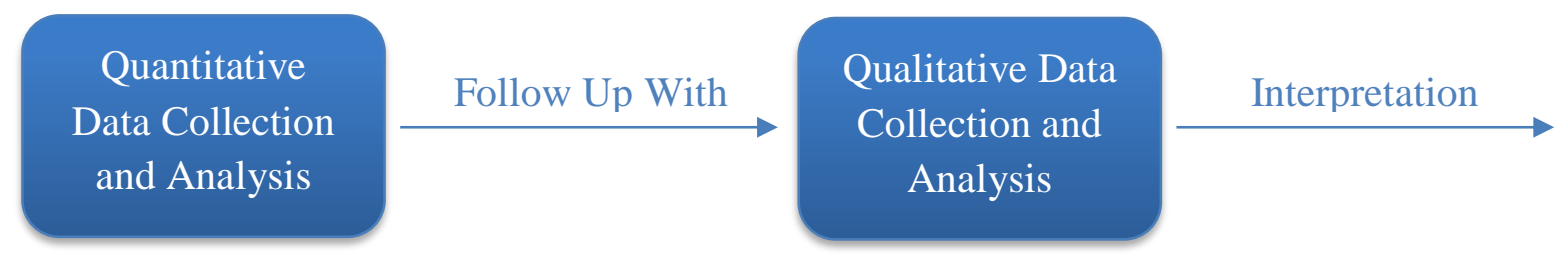

Figure 1. Sequential Explanatory Design

Source: (Creswell, 2012)

This research describes the effect of students' responses based on the student's solo taxonomy in mathematics learning towards the activeness and learning outcomes. First, the quantitative data were obtained by observing the students' activeness in the learning process for six meetings. Furthermore, a written test was given after learning had been completed and then followed by distributing questionnaires as a benchmark for the level of the taxonomy solo. Response scores, activeness, and learning outcome scores were analyzed using descriptive and inferential statistics. Second, structured interviews were conducted to find out the cause of the mistakes. The results of the interview were analyzed narratively.

The research subjects consisted of 5 students who met the response criteria based on a solo taxonomy. One student was in positive response category (extended abstract), one student was in the tended to be positive response category (relational), one student was in the normal response category (multi-structural), one student was in the negative response category (Unistructural), and one student was negative response category (pre-structural). Responses indicators based on solo taxonomy can be seen in Table 1.1 . 
Table 1. Responses Indicators Based on Solo Taxonomy

\begin{tabular}{|c|c|c|c|}
\hline No & Category & Response Level & Indicators \\
\hline 1 & Positive & $\begin{array}{c}\text { Extended } \\
\text { Abstract }\end{array}$ & $\begin{array}{l}\text { Students use some information then apply them to the } \\
\text { concept, provide results, link them to other information, then } \\
\text { draw relevant conclusions to generalize the results obtained. }\end{array}$ \\
\hline 2 & $\begin{array}{l}\text { Positive } \\
\text { Tendency }\end{array}$ & Relational & $\begin{array}{l}\text { Students use some information then apply them to the } \\
\text { concept, provide results, then connect them to other } \\
\text { information. }\end{array}$ \\
\hline 3 & Normal & Multi-structural & $\begin{array}{l}\text { Students use some information but there is no relationship } \\
\text { among the data, so they cannot draw relevant conclusions and } \\
\text { connect information to new information. Since the } \\
\text { relationship is irrelevant, so the conclusion is also not } \\
\text { relevant. }\end{array}$ \\
\hline 4 & $\begin{array}{l}\text { Negative } \\
\text { Tendency }\end{array}$ & Uni-structural & $\begin{array}{l}\text { Students only use at least one information and use one concept } \\
\text { or process of solving and drawing conclusions but the } \\
\text { conclusions obtained are not relevant. }\end{array}$ \\
\hline 5 & Negative & Pre-structural & $\begin{array}{l}\text { Students use incorrect data or process of solving, so the } \\
\text { conclusions obtained are incorrect, cannot form a unified } \\
\text { concept at all, do not have any meaning, and unable to do the } \\
\text { tasks given correctly. }\end{array}$ \\
\hline
\end{tabular}

Source: (Hayuhantika, 2017)

Table 1.1 illustrates the categorization of five levels of student response categories based on the solo taxonomy. It is used to describe the effect of students' responses based on solo taxonomy on the students' activeness and learning outcomes.

\section{RESULTS AND DISCUSSION}

The results of the analysis can be seen in table 1.1.

Table 2. The Analysis of Responses, Activeness, and Learning Outcomes

\begin{tabular}{ccccc}
\hline Respondents & Solo Taxonomy & Response Category & Activeness & Learning Outcomes \\
\hline AS & Extended Abstract & Positive $(4,0)$ & Very active $(3,8)$ & Excellent (94) \\
SS & Relational & Positive Tendency (3,0) & Active (3.3) & High (83) \\
TT & Multistructural & Normal $(2,0)$ & Active $(2,6)$ & Moderate (75) \\
MF & Uni-structural & Negative Tendency (1,5) & Active $(2,5)$ & Moderate (74) \\
AM & Prestructural & Negative $(1,0)$ & Less Active $(2,3)$ & Low (55) \\
\hline
\end{tabular}

A positive response (extended abstract) shows a high influence on learning outcomes, positive tendency response (relational) shows a high influence on learning outcomes, normal response (multi-structural) shows a moderate influence on learning outcomes, negative tendency response shows a moderate influence on learning outcomes, and negative responses (unistructural) shows a low influence on learning outcomes. The simple linear regression test results show that $\mathrm{t}_{\text {observed }}=9.07$ with a significant level of $0.01<0.05$, then $\mathrm{H}_{0}$ is rejected and $\mathrm{H}_{1}$ is accepted. It means that is a significant influence of students' responses based on a solo taxonomy on student learning outcomes.

The very active category shows a very high influence on learning outcomes, the active category shows high and moderate influences on learning outcomes, and less active category shows a low influence on learning outcomes. The results of a simple linear regression test show that $t_{\text {observed }}=3.71$ with a significant level of $0.04<0.05$, then $\mathrm{H}_{0}$ is rejected and $\mathrm{H}_{1}$ is accepted. It means that there is a significant effect of activeness on students' learning outcomes. 
Positive responses category (extended abstract) and very active category are directly proportional to the high learning outcomes, positive tendency response (relational) and active category are directly proportional to the high learning outcomes, normal response category (multi-structural), and negative tendency (uni-structural) with active category shows moderate effects on learning outcomes, and negative responses category (pre-structural) and less active category are directly proportional to the low learning outcomes.

Based on the interview, US belonged to the extended abstract response (positive category) and obtained a very high learning outcome. It could be seen from effective and efficient works. As for the activeness, US belonged to the very active category. It was supported by the results of the interview about the learning process favored by US which was sharing information and criticizing one another.

The subject in the extended abstract category was able to use some data in gathering information then applied the concepts to provide temporary results. The results were then connected to other concepts so that the subject could draw relevant conclusions and made generalizations. The results are in line with the results of the study by Wardani et al (2017) that state that the extended abstract subjects are characterized of being able to determine a more effective way to solve different problems, namely using substitution methods, able to think conceptually, and able to explain their interrelationships in more general contexts. Based on the description, it can be interpreted that students who are at the extended abstract response category or in the positive category are directly proportional to the high activeness and learning outcomes.

Based on the interview, SS belonged to the relational category (positive tendency) and obtained a high learning outcome. It can be seen from her ability to briefly solve the questions with minimum explanation. As for the activeness, SS was in the active category. It means that there were lacking aspects of activities. It can be seen from the results of the interview where some group members did not care about their friends. It was the reason why SS's activeness was only in the active category.

The subjects in the relational category were able to use some information, apply them to the concepts, provide interim results, and then draw relevant conclusions. The subjects were able to relate some concepts so that all information is relevant to the conclusions. However, it contradicts the results of research by Ekawati et al (2013) which states that the subjects in the relational category are unable to apply the concepts, process and then provide interim results, and connect the data or other processes. These differences can be seen from the results of the interviews on activeness in the group learning process so that they can relate one concept to another.

Based on the description, it can be interpreted that students who are at the relational response category with positive tendencies are directly proportional to the active category of activeness and high learning outcomes.

\section{Multi-structural Response (Normal)}

The following is a brief description of the results of interviews with the third respondents (TT).

Researcher Why did you solve the first question by drawing small circles?

TT It is easier to fill the empty spaces

Researcher On the second question, how did you determine the $2004^{\text {th }}$ terms? 
TT

Researcher

TT

researcher

TT
I was guessing, but there was a pattern that I used but I could not write which were the multiplicative of 10, 100, 1000 numbers.

How did you complete the number pattern on the third question?

The pattern's sequence numbers were 4, 5,7,10,14, 19, and 25. Add 1

point on each sequence.

What is your opinion about group works?

I love it because of the concept of learning by playing with so many

friends although some do not want to share their answers.

Based on the interview results, TT belonged to the multi-structural response (normal category) and obtained a moderate learning outcome. It was supported by the way of answering questions that did not have basic workmanship, only relied on logical abilities. As for the activeness, TT was in the active category, meaning that there were some lacking aspects of activities. The activity can be seen from the results of interviews where TT stated that learning by playing was fun but we should focus more on the learning. That is why TT is in the medium category.

The subjects in the multi-structural response level were able to use some information although there was no relationship between the data. They could not draw relevant conclusions and make some relationships from some information. Since the relationships were incorrect, the conclusions obtained were also irrelevant. It is in line with the results of the study conducted by Wardani et al (2017) where multi-structural subjects can look for additional information for the problem and can make some relationships from some information obtained previously, although they are incorrect. Based on the description, it can be interpreted that students who are at the multi-structural response level are in the active category with moderate learning outcomes.

\section{Uni-structural Responses (Negative Tendency)}

The following is a brief description of the results of interviews with the fourth respondents (MF).

$\begin{array}{ll}\begin{array}{l}\text { Researcher } \\ \text { MF }\end{array} & \text { Why did you solve the first question by drawing small circles? } \\ & \text { by } 1 \text {, so the last small circle is the } 36^{\text {th }} \text {. } \\ \text { Researcher } & \text { Why didn't you do the second question? } \\ \text { MF } & \text { I forgot, even though I remembered during the group discussion. } \\ \text { Researcher } & \text { How did you solve the numerical pattern in the third question? } \\ \text { MF } & \text { Well, by looking at the pattern of } 4,5,7,10,14,19, \text { and } 25 . \text { The } \\ \text { difference of } 4 \text { to } 7 \text { is } 3,5 \text { to } 10 \text { is } 5 .\end{array}$

Based on the interview, MF belonged to the uni-structural response level (negative tendency) and obtained a moderate learning outcome. It can be seen from how MF though an easy problem as a hard one. As for the activeness, MF belonged to the active category, meaning that there are some lacking aspects of activities. It can be seen from MF's discomfort of group learning so that his activeness was in the medium category. 
The subjects in the uni-structural response level were only able to use at least one information and one concept, yet the conclusions obtained were irrelevant. These results contradict the results of the study conducted by Asikin (2002) which states that the subjects in the uni-structural response level are characterized by being able to draw the right conclusions based only on one suitable data. The occurrence of this difference can be seen from the results of interviews about the displeasure in group learning because the subjects felt disturbed by other friends and made them unable to conclude correctly.

Based on the description, it can be interpreted that students who are at the uni-structural response level or the negative tendency category are in the active category of activeness with moderate learning outcomes. Based on the interview results, AM belonged to the pre-structural response level (negative category) with low learning outcomes. It was supported by the incorrect answers. As for the activeness, AM belonged to the less active category, meaning that there were some lacking aspects. The activeness can be seen from the results of the interview where AM states that he felt discomfort when learning in groups. Based on the description, it can be interpreted that students who are at the pre-structural response level or in the negative category are less active with low learning outcomes.

The subjects at the pre-structural response level could not use the information in problemsolving so that the conclusions obtained were incorrect. They could not do the task precisely which means that they did not have the skills that can be used in completing the given task. However, those results contradict the results of research conducted by Wardani et al (2017) where the pre-structural subjects can use the information provided. The difference can be seen from the results of students' interviews about the lack of ability to adapt to group members and do not have the skills in finding information to solve given problems

It can be concluded that students' responses affect the activity and learning outcomes. These findings support the results of research by Agustya (2017) on the effect of responses toward learning outcomes. The solo taxonomy provides a huge contribution toward learning outcomes and supports the results of research by Yang et al (2019) about the influence of activeness towards students' learning outcomes. Although the activeness is varied, it can be concluded that the skills or activeness influence the learning outcomes. The results of this study contribute to the science of understanding the response of the solo taxonomy that can be seen from the students'activeness and learning outcomes.

The novelty of this research lies in the obtained information that the responses based on the solo taxonomy are directly proportional to the students' activeness and learning outcomes as can be seen from the positive responses that are obtained from the high activeness and high learning outcomes. It means that the more active and higher the learning outcomes, the positive responses will, even more, be generated. Students' positive responses are identified based on the activeness and the high learning outcomes so that the more positive the response, the more active and the higher the learning outcomes.

\section{CONCLUSIONS}

Based on the results of research and discussion, in general, the students' response based on the solo taxonomy in mathematics learning affects the activeness and learning outcomes. students who are at the extended abstract response level are classified as very active and having very high learning outcomes, students who are at the relational response level are identified as active 
and having high learning outcomes, students who are at the multi-structural response level are identified as active and having moderate learning outcomes, students who are at the Unistructural response level are identified as active and having moderate learning outcomes, and students who are at the pre-structural response level are identified as less active and having low learning outcomes.

After knowing the indicators of students' responses based on the solo taxonomy that affects the activeness and learning outcomes, it is expected that the understanding obtained from this study can be a reference or literature for further research, especially research related to solo taxonomy.

\section{ACKNOWLEDGMENT}

The Author would like to thank Kementerian Riset dan Teknologi of the Republic of Indonesia for providing research grants for novice lecturers, so that this research can be carried out.

\section{AUTHOR CONTRIBUTIONS STATEMENT}

$\mathrm{AK}$ and $\mathrm{NH}$ are the main drafters of this study. They complete the research together and write it down in the form of an article.

\section{REFERENCES}

Agustya, Z. (2017). Pengaruh respon peserta didik tentang proses pembelajaran terhadap hasil belajar peserta didik kelas X pada mata pelajaran ekonomi di SMA negeri 1 wonoayu kabupaten Sidoarjo. Jurnal Pendidikan Ekonomi., 5(3), 1-6.

Asikin, M. (2002). Penerapan taksonomi SOLO dalam pengembangan item tes dan interpretasi respon mahapeserta didik pada perkuliahan geometri analit. Laporan penelitian. FMIPA UNNES tidak diterbitkan.

Ataupah, D. A. (2018). Peningkatan hasil belajar biologi materi sistem gerak melalui model pembelajaran kooperatif tipe make a match peserta didik kelas-XI IPA SMA negeri 8 Malang. JINoP (Jurnal Inovasi Pembelajaran), 4(1), 11-16.

Casey, K., \& Azcona, D. (2017). Utilizing student activity patterns to predict performance. International Journal of Educational Technology in Higher Education, 14(1), 1-15.

Creswell, J. W. (2012). Educational research: planning, conducting, and evaluating quantitative and qualitative research. 4th edition, Boston: Pearson.

Ekawati, R., Junaedi, I., \& Nugroho, S. E. (2013). Studi respon peserta didik dalam menyelesaikan soal pemecahan masalah matematika berdasarkan taksonomi solo. Unnes Journal of Research Mathematics Education, 2(2), 101-107.

Hariyanto, Y. (2015). Pengaruh metode pembelajaran tipe talking chips terhadap hasil belajar peserta didik pada kompensasi dasar memahami model atom bahan semi konduktor di SMK negeri 1 jetis Mojokerto. Jurnal Pendidikan Teknik Elektro, 04(03), 999-1005.

Hasan, B. (2017). Karakteristik respon peserta didik dalam menyelesaikan soal geometri berdasarkan taksonomi solo. JINoP (Jurnal Inovasi Pembelajaran), 3(1), 449-458.

Hayuhantika, D. (2017). Pemetaan respon peserta didik SMP berdasarkan taksonomi solo 
dalam penyelesaian masalah generalisasi pola. JP2M (Jurnal Pendidikan Dan Pembelajaran Matematika), 2(2), 92-105.

Hendriana, H., Purwasih, R., Triawan, E., Prasetio, Y., \& Satria, T. (2018). Analysis of student problem solving skill and activity concentration on a senior high school. Al-Jabar: Jurnal Pendidikan Matematika, 9(1), 1-8.

Kaharuddin, A. (2013). Effectiveness comparative of scientific approach elpsa and open-ended setting cooperative stad types of mathematics learning at VII class SMP negeri of a accreditation in Makassar. Jurnal Daya Matematis, 1(1), 29-44.

Kaharuddin, A. (2019). Effect of problem based learning model on mathematical learning outcomes of 6th grade students of elementary school accredited B in Kendari city. International Journal of Trends in Mathematics Education Research, 1(2), 43-46.

Kaharuddin, A., \& Liasambu, L. (2019). Penerapan model STAD dalam meningkatkan hasil belajar dan aktivitas siswa SMP. Jurnal Pendidikan Matematika Raflesia, 4(2), 29-37.

Lake, D. (1999). Helping students to go SOLO: teaching critical numeracy in the biological sciences. Journal of Biological Education, 33(4), 191-198.

Lian, L. H., \& Yew, W. T. (2012). Assessing algebraic solving ability: A theoretical framework. International Education Studies, 5(6), 177-188.

Mulbar, U., Rahman, A., \& Ahmar, A. S. (2017). Analysis of the ability in mathematical problem-solving based on SOLO taxonomy and cognitive style. World Transactions on Engineering and Technology Education, 15(1), 68-73.

Novianti, W. E., Ertikanto, C., \& Wahyudi, I. (2014). Pengaruh aktivitas terhadap hasil belajar IPA melalui scientific approach dengan bantuan BSE widian. Jurnal Pembelajaran Fisika, 2(4), 145-157.

Nurmala, D. A., Tripalupi, L. E., \& Suharsono, N. (2014). Pengaruh motivasi belajar dan aktivitas belajar terhadap hasil belajar akuntansi peserta didik kelas X akuntansi SMK negeri 1 Singaraja tahun pelajaran 2013/2014. Jurnal Pendidikan Ekonomi Undhiksa, $4(1), 1-10$.

Putri, D. A. K. (2014). Analisis kesalahan peserta didik dalam menyelesaikan soal yang berhubungan dengan konstruksi statis tertentu berdasarkan taksonomi solo plus pada kelas Xtgb SMK negeri 3 Surabaya. Jurnal Kajian Pendidikan Teknik Bangunan, 3(1), 59-66.

Sadikin, S., \& Kaharuddin, A. (2019). Identifikasi kemampuan komunikasi matematika ditinjau dari self-concept matematis dan gender. Prosiding SNPMAT, 2(1), 190-198.

Tawarah, H. M. (2013). Teachers' effectiveness in asking classroom's questions and their interaction with student responses and questions. International Journal of Educational Sciences, 5(2), 117-122.

Tomlinson, C. A., Brighton, C., Hertberg, H., Callahan, C. M., Moon, T. R., Brimijoin, K., \& Reynolds, T. (2003). Differentiating instruction in response to student readiness, interest, and learning profile in academically diverse classrooms: A review of literature. Journal for the Education of the Gifted, 27(2-3), 119-145.

Vrettaros, J., Vouros, G., \& Drigas, A. (2006). An intelligent system for solo taxonomy. IFIP 
International Federation for Information Processing, 228(2), 421-430.

Wardani, N. K., Sutopo, S., \& Pambudi, D. (2017). Profil respons peserta didik berdasarkan taksonomi solo dalam memecahkan masalah matematika pada materi pokok lingkaran ditinjau dari. Pendidikan Matematika Dan Matematika (JPMM), 1(4), 91-107.

Yang, T., Baker, R. S., Studer, C., Heffernan, N., \& Lan, A. S. (2019). Active learning for student affect detection. The 12th International Conference on Educational Data Mining, (Edm), 208-217. 